which they have been subjected on their downward course; but, at the same time, he distinguishes between these veins-the result of stratification, and others which he terms bands of infiltration, and which he believes to have been formed by the infiltration and freezing of water.

The late Principal I. D. Forbes maintained ("Occasional Papers on the Theory of Glaciers," I3th letter) that the veins of stratification were annihilated at a certain point, and that at precisely the same time other veins, approximately at right angles to the former ones, were formed. These effects he referred to intense pressure.

Professor Tyndall ("Glaciers of the Alps," pp. 380, 425-6), agrees with Professor Forbes "in ascribing to the structure a different origin from stratification," and, if I understand him rightly, does not believe that any portion of the (approximately) vertical veins have such an origin. He divides the veins into marginal, transverse, and longitudinal structure, and asserts that all are produced by pressure, which causes partial liquefaction of the ice, and that the water is refrozen when the pressure is relieved.

If any one cause produced the whole of the veins of pure ice that are found in the imperfect ice of glaciers (which all are agreed are a constitutional feature of those bodies), it is obvious that that cause would have to be equally generally distributed. It is indisputable that all the veins are not veins of stratification, because examples have been frequently observed crossing (cutting) the strata lines at a larger or smaller angle. But although such observations prove conclusively that all the veins must not be attributed to stratification, they do not prove any more.

believe, with Professor Agassiz, for reasons advanced elsewhere, it can be demonstrated, equally conclusively, that many of the veins which are seen in the lower courses of glaciers in the Alps are veins originally produced by stratification, and dissent entirely from the "annihilation" of Principal Forbes. But as it is proved that some have a different origin, we must look to other causes for an explanation. It is probable that the theories quoted above offer a practical solution of the difficulty, although they are unfortified by direct proofs. But I have seen examples which it was difficult to explain by either one or the other.

There is one means by which the veins might be produced, which, if not overlooked, is at least not generally advanced. All glaciers have crevasses; a glacier is known by its crevasses. The sides of all crevasses become more or less weathered and coated with a glaze of pure ice. When they close up again, when the sides join by virtue of regelation, does this leave no trace? Can it be annihilated? Or, do the two coalesced films leave their mark as a vein of pure ice throughout the generally whitish mass of the glacier? I consider a large number of the veins of pure ice which constitute the "veined structure" of glaciers as nothing more than the scars of healed crevasses.

It is not easy to say whether this was the meaning of the followin passage, taken from p. 201 of Forbes's "Occasional Papers :" "Most evidently, also, the icy structure is first induced near the sides of the glacier where the pressure and working of the interior of the ice, accompanied with intense friction, comes into play, and the multitudinous incipient fissures occasioned by the intense strain are reunited by the simple effects of time and cohesion." Judged by his preceding pages, it is not, and I am unaware that it has been, advanced in any other place. Some of your readers may perhaps be able to throw some light upon the subject.

Dec. 13,1869

EDWARD WHYMPER

\section{Irish Lepidoptera}

IN reply to the note appended to the report of the Dublin Natural History Society's Meeting, Dec. Ist (NATURE, No. 6, p. I 76), allow me to say that I perfectly remember the specimen of Liminitis to which Mr. Andrews refers, and which he exhibited some years ago as Liminitis Sibylla from Tarbert in the county of Limerick. It was subsequently given by him to my friend Mr. A. Dunlop, of Sutton, near Dublin, and sent to me for identification.

I examined it carefully, and it is a specimen of Linzinzitis Camilla, and of Continental origin. How it came to be mixed with Mr. Andrews's Irish specimens remains for him to explain.

To say that the insect is neither Sibylla nor Camilla is absurd; these are the only two species of the genus which inhabit Europe; and Camilla, to which Mr. Andrews's specimen belongs, is the most unlikely of the two to occur in Ireland, as Sybilla is found in England, but not Camilla. However, the insect is in Mr.

* British Assaciation, $x 866$ (Nottingham).
Dunlop's Collection, and I am sure that gentleman will have pleasure in allowing anyone to inspect it.

As to Chrysophanus Virgaurea, there is no British specimen known, nor is there any trustworthy record of the capture of the species in the British Islands.

Chrysophanus Hippothoe (variety Dispar) was formerly taken in profusion in the fen districts of Cambridge and Huntingdon, but not that I am aware of in any other part of England. It has been extinct for many years as a British insect, and there is no record of its capture in Ireland at any time. Mr. Andrews's statement that he "met with" Dispar in Kerry is indefinite. Did he capture it? or did he only see it, or suppose he saw it? The most experienced collector may mistake an insect on the wing; and delighted as entomologists would be to welcome back the long-lost Hippothoe, they will require very different proof of its reappearance to any which has yet been adduced.

EDWIN BIRCHALI

Airedale Cliff, Newlay, near Leeds, Dec, 20, I869

\section{Deep Sea Corals}

IN the postscript to Mr. J. Gwyn Jeffreys's report on the "Deep-sea Dredging Expedition in H.M.S. Porcupine," I notice the following sentence:- "The presence of corals at great depth. will also materially alter the views generally received of the depth at which reef-builders may work, and modify to a certain extent Darwin's theory of the reefs and their mode of growth." This opinion has gained much credence, but it is founded upon error, and is a mistake. Count Pourtales has been good enough to send me the commonest corals which he dredged up off Florida and the Havana from depths greater than I oo fathoms. He has forwarded also the description of the species, and a note upon the nature of the genera represented in the depths of the Gulf of Mexico, and which have not been as yet described. I have received the greater part of the corals dredged up during the expedition in the Porcupine, and have examined the specimens carefully. Being thus acquainted with the deep-sea coral fauna of both sides of the Atlantic, and having a previous knowledge of the species of the Mediterranean, I have no hesitation in asserting that there is not one species. found in these deep seas which is "reef-building" in its habit or whose structures resemble those of the true reef forms. $\mathrm{Mr}$. Darwin's theory is therefore as yet as strong as ever.

Dec. 23, 1869

P. Martin Duncan

\section{A Meteor}

My attention has just been called to an error in my letter of November 6, which appeared in NATURE, p. 58 , respecting the meteor of that evening. I refer to the stalement that, of the meteor-clond, the "longest axis was in the line from the north-west point of the horizon to the pole-star." Instead of north-west, it should have been south-zeist, or, perhaps, more correctly, S. W. by W.

Lamorna, Torquay, Dec. 31, I869

\section{NOTES}

THE trigonometrical survey of England and Wales, on the scale of one inch to a mile, has been completed during the past week. It was commenced in the year I $79 \mathrm{I}$.

TELEGRAPHIC connection with Australia is about to be carried out by the British-Australian Telegraph Company. The work will consist of 563 miles of cable from Singapore to Batavia, and will join the Dutch line which crosses to the south-eastern extremity of Java, from which point another cable of 1,163 miles is to be laid to Port Darwin. A land line of about 800 miles will connect this with all the Australian colonies. From England to Singapore the messages will be taken by the Falmouth and Malta, the Anglo-Mediterranean, and the British-Indian Extension Companies; thus forming a complete route.

THE eighth part of Wurtz's Dictionnaire de Chimie has just been issued. The Revue des Cou's Scientifiques, to which we are indebted for this anpouncement, calls particular attention to the articles Eaux and Composés dïazö̈ques by M. Gautier, Dissocia* tion by M. H. Debray, and Engrais by M. Dehérain.

THe Agricultural Academy of Poppelsdorf, near Bonn, has recently sustained a severe loss in the death of its able and ener- 